\title{
THE INFLUENCES OF THE EFL COLLEGE IRAQI WRITING INSTRUCTORS' BELIEFS On the Feedback of EFL College Learners' Writing
}

\section{MOHAMMED HASAN MAHDI H. ALBOBDAIR ${ }^{1}$}

${ }^{1}$ M.A. in English / Linguistics, Ministry of Education, Directory of Education in Babylon, Republic of Iraq E-Mail: muhammedhassan1969@gmail.com

Published at 01/08/2021

Accepted at 24/07/2021

\begin{abstract}
The current study aims at investigating the relationship between EFL writing teachers' beliefs in their own abilities to teach EFL writing, and to study how their selfperceptions of efficacy would influence their feedback to their students' writing. The study is designed to examine the self- efficacy of (20) EFL writing instructors in AlMuthanna University using as primary data sources a questionnaire and interviews and the feedback given on students' writing samples. Most of the data are analyzed using a constant comparative approach. In addition, some of the data from the questionnaires and writing samples produced descriptive statistics. Findings are reported in a grounded theory format, with a description of a model of the relationship between teachers' self-efficacy and the feedback they provided to their students' writing. The findings of this study suggest that in teaching college-level EFL writing, teacher feedback on students' writing was not influenced exclusively by their writing self- efficacy. In the EFL writing context, teachers chose how they would give comments on students' writing depending on whether they believed they could contribute to the students' writing improvement. In other words, their teaching efficacy in EFL writing played a more important role in determining how they provided feedback to their students' writing. The conceptions of their role as EFL writing teachers differed depending on the clarity of their role, confidence in performing the role, and positive expectations about change in students' writing. Two major conclusions were drawn from the data. First, college- level EFL writing instructors' writing selfefficacy was high in English . However, their feedback did not reflect their efficacy beliefs about their own writing. Second, in many aspects of giving feedback, it became important whether writing teachers had clear conceptions of the role they played in helping students improve their EFL writing or not.
\end{abstract}




\section{تأثير هعتقدات هدرسي" الكتابة العراقيين للغة الإنكليزية كاغة أجنبية في التغذية الراجعة

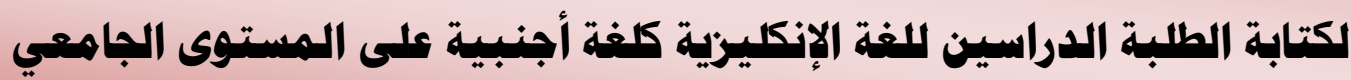

\section{م. م. محمد حسن مهدي ألبو بلير 1}

1 الماجستير في اللغة الإنجليزية / اللغويات ، جمهورية العراق، وزارة التربية، المديرية العام للتربية في بابل البريد الاليكتروني: gmail.com

تاريخ القبول: 2021/07/24م

تاريخ النشر: 2021/08/01م

تهدف الدراسة الحالية إلى البحث في العلاقة بين معتقدات مدرسيّ الكتابة في اللغة الإنكليزية كلغة أجنبية في قدراتهم لتدريس الكتابة في اللغة الإنكليزية كلغة أجنبية و تفحص كيف أن إدراكاتهم الذاتية لقوة التأثير يمكن أن تؤثر في التغذية الراجعة لكتابة

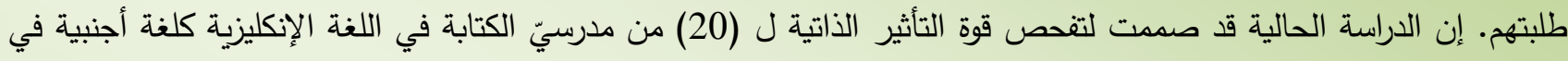

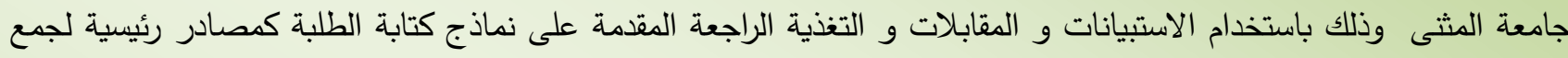
البيانات. إن أغلب البيانات المتحصلة من الاستبيانات قد تم تحليلها نوعيا و ذلك استخدام اسلوب مقارن ثابت. و بالإضافة إلى لى

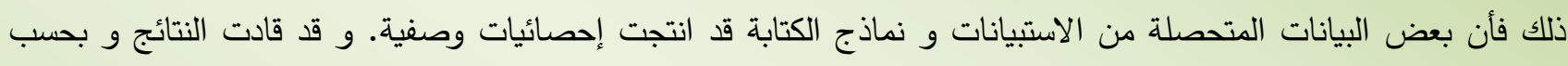
تصميم نظري, مع وصف لنموذج العلاقة بين قوة التأثير الذاتية للمدرسيين و التغذية الراجعة التي يقدمونها لكتابة طلاتهم. إن نتائج

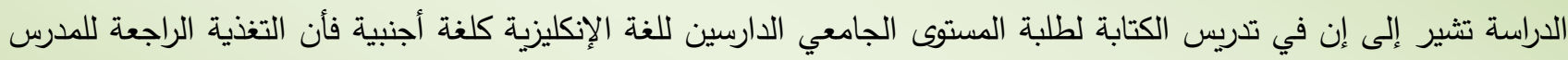

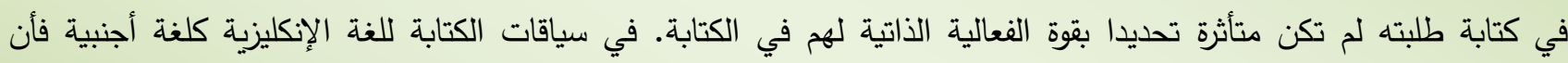

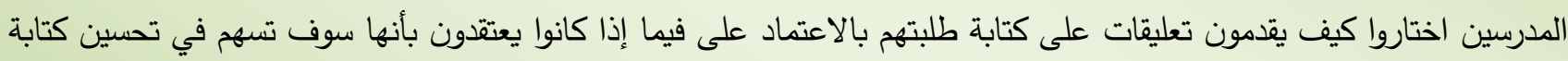

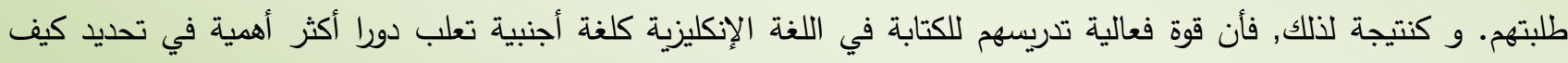

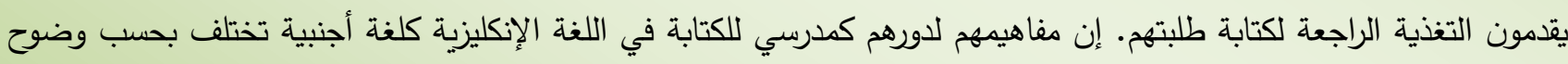

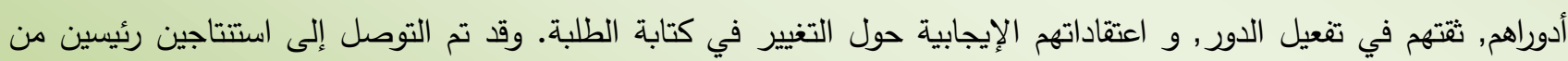

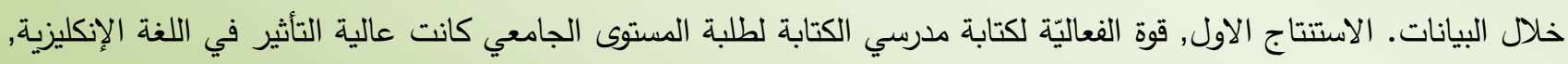

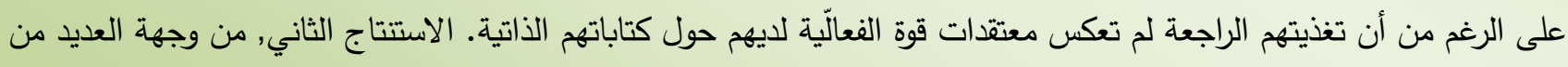
الجوانب في تقديم التغذية الراجعة, فقد أصبح من المهم فيما إذا كان لمدرسي الكتابة مفاهيم واضحة للدور الذي لئي يلعبونه في مساعدة

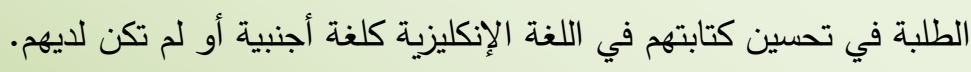




\section{Introduction}

The interest in the present study was to investigate the relationship between EFL writing teachers' self-efficacy in their writing and the feedback they provide on students' writing in the Iraqi university context. By using both quantitative and qualitative methodologies, I expected to find how non-native EFL writing teachers' writing self-efficacy would influence the patterns of their feedback practices. Being aware of what they could do as EFL writing teachers and confident in performing the role, non-native EFL writing teachers could exert themselves in providing feedback that was effective in improving their students' EFL writing. Therefore, the EFL writing teachers' teaching efficacy became for me an important area of inquiry in the present study.

Since the late 1980's, the role of self-efficacy in academic settings has been investigated by an increasing number of researchers. Among other academic activities and skills, a group of researchers have found a direct relationship between writing self-efficacy and writing performance (Shell, Murphy, \& Bruning, 1989; Pajares \& Johnson, 1994). How students perceive their writing abilities influences what and how they write. For instance, students who underestimate their writing skills are not likely to involve themselves in tasks that require writing skills. Thus, it is important to look at students' perceived abilities in order to understand their writing competence.

Teachers' role in the development of students' writing self-efficacy cannot be overly emphasized. Although teachers are an important part of the classroom environment, writing teachers' self-efficacy beliefs, specifically in the foreign language classroom context, have not been investigated. Teachers' beliefs in their competence have been identified as an influential factor in students' academic motivation and achievement, both indirectly and directly (Midgley, Feldlaufer, \& Eccles, 1989; Tschennen-Moran, Hoy, \& Hoy, 1998). Therefore, it seemed reasonable to argue that this would be the case in the foreign language writing classroom as well. In other words, the way foreign language writing teachers who are themselves non-native speakers of the language believe in their writing and teaching abilities seemed likely to influence how they teach their students.

\subsection{Statement of the Problem}

Among other instructional practices in the EFL writing classroom, feedback from their teachers is the primary source of EFL performance evaluation available to students. Therefore, it is necessary to investigate how the EFL writing teachers' efficacy beliefs are related to the feedback they give their writing students. In this study, the 
researcher was interested in understanding whether teachers' beliefs in their self-efficacy as EFL writing instructors influenced their interaction with and feedback given to students in an EFL context in Iraq.

When a writing teacher feels unsure of his or her writing abilities, he or she is more likely to give feedback that centers on local problems, such as lexical mistakes or grammatical errors. By focusing chiefly on this more narrow scope of writing, teachers do avoid the possibility of exposing their perceived weakness in their writing abilities in the foreign language. At the same time, when a teacher is confident in his or her writing abilities, he or she is willing to share his or her knowledge with students (Calkins, 1998). Such a teacher is more likely to focus on pragmatic errors or on the global context of a student writing. In addition, when teachers believe they will have a positive effect on their students' developing performance and competence, they will provide more encouraging feedback (McLeod, 1995). This support is especially important in writing classrooms, where improvement is perceived being so slow and is most difficult to assess. Therefore, it seems very likely that the perceived EFL writing abilities of non-native writing teachers affect how and what kind of feedback they will give to their students.

\subsection{The Aims of the Study}

The goal of this research is to examine writing instructor's belief in his or her own ability to teach EFL writing, and to investigate how this self-efficacy influence their interaction with EFL students . The general research aims are as follow.

1-To examine how confident are the EFL writing instructors in their abilities in giving feedback to their students? What is their attitude toward their own writing in English? Specifically, is there any difference in their self-efficacy in writing among participants according to their educational background.

2-To How know how EFL teachers' self-efficacy in writing affect different kinds of feedback and the different ways of providing feedback that they give to students in an EFL program.

\section{Review of Related Literature}

The present study focuses on EFL teachers and how they respond to their students' writing. As discussed previously, self-efficacy in teaching writing in a second or foreign language has rarely been investigated. Moreover, research on foreign language writing has is sparse because it has been often misunderstood or confounded with second language writing. 
Thus, this study depends heavily on the previous research on writing instruction's and teacher's feedback in EFL writing classrooms for its theoretical background.

\subsection{Teachers' Beliefs and Self-Efficacy}

To understand the relationship between teachers' self-efficacy and their teaching behavior, self-efficacy theory in general must be investigated first. Among many interacting factors, self-efficacy beliefs have been identified as one of the strongest predictors of academic performance (Wachholz \& Etheridge,1996). Bandura (1986) defined selfefficacy as "people's judgments of their capabilities to organize and execute courses of action required to attain designated types of performances." According to self-efficacy theorists, people can exert influence on how they behave.

Self-efficacy beliefs are important because possessing skills is different from being able to integrate and apply them according to different circumstances. Thus, human behavior cannot be understood as simply the sum of knowledge and skills. Ability is not a fixed attribute, but a generative mechanism that mediates cognitive, social, motivational, and affective processes to fulfill different purposes in a task situation (Bandura, 1993). Through self-efficacy beliefs, individuals evaluate their abilities and thought processes, set their goals for the task, and generate subsequent action, generally explaining why individuals' performance differs even when they have similar knowledge and skills for the task (Bandura,1997). Therefore, even highly capable individuals can misappropriate their abilities under circumstances that debilitate their efficacy beliefs (Bandura \& Jordan, 1991).

Self-efficacy is not a factor that passively predicts future performance, but rather it actively affects various dimensions of individuals' behavior. Efficacy beliefs influence how they understand situations and visualize future success (Bandura \& Wood, 1989). The stronger the efficacy they perceive for themselves, the higher the goals they set for themselves and the firmer the commitment they exert to the task (Bandura, 1991; Shunk \& Swartz, 1993). In addition, individuals who believe they can manage their difficulties are not likely to be disturbed by their anxiety and stress (Bandura, 1993)

\subsection{Writing Self-Efficacy}

Among other academic skills, writing is a skill that requires integrating and applying multiple sub-skills (Hayes \& Flower, 1980). As a complex cognitive task, writing performance must also be mediated by efficacy beliefs (Shell, Murphy, \& Bruning, 1989). Writing self-efficacy has been shown to be related to academic achievement by a group of researchers (Bandura, 1992). 
Self-efficacy about writing, like all efficacy beliefs, is also influenced by prior experiences. That is, writing self-efficacy is developed through previous achievements and failures in writing.

Along with a focus on writing self-efficacy, for the purpose of this study, teacher efficacy as well must be considered as another influential factor in how teachers give feedback as another teaching behaviors. Therefore, investigating how EFL teachers believe in their abilities to teach EFL students will also help us understand the relationship between EFL writing self- efficacy and non-native EFL writing teachers' feedback behavior.

\subsection{Teacher Efficacy}

Teachers play an important part in influencing the classroom environment. Teachers' affect may influence various aspects of their behavior as well (Emmer,1991). Teacher efficacy has been investigated in order to explain why individual teachers vary in teaching effectiveness. Teacher's efficacy has been defined as "the teacher's beliefs or conviction that they can influence how well students learn, even those who may be difficult or unmotivated" (Guskey \& Passaro, 1994). Teachers' beliefs in their efficacy determine to some extent how they organize classroom activities and evaluate students' academic capabilities (Bandura, 1997). That is, teachers with higher efficacy believed that they could strongly influence student achievement and motivation (Tschannen-Moran, Hoy, \& Hoy, 1998).

Gibson and Dembo (1984) constructed an instrument to measure teacher efficacy. Two factors were found, personal teaching efficacy and general teaching efficacy. Personal teaching efficacy refers to an individual's perception of his or her own teaching abilities. It includes items such as "If I really try, I can get through to most difficult students." General teaching efficacy refers to a teacher's expectation of his or her influence on students' learning. It consists of items such as "a teacher is very limited in what he/she can achieve because a student's home environment is a large influence on his/her achievement." Although researchers have found inconsistent results to confirm the existence of the two factors, they have generally supported the predictions that Gibson and Dembo had made (Tschannen-Moran, Hoy, \& Hoy, 1998). They also have suggested that teacher efficacy influences certain patterns of classroom behavior that affects students' achievement gains.

\subsection{Feedback}

Before discussing the issues of feedback, the researcher will discuss how feedback has been considered in writing instruction. First, the study will examine the role of teachers in EFL classrooms where feedback takes place. Then, the studywill discuss how the role of 
feedback has been defined depending on the perceived role of EFL teachers in writing instruction.

\subsubsection{The Perceived Roles of ESL/EFL Teachers in Giving Feedback}

It would seem important to examine the roles of (English as a second language) or (English as a foreign language) teachers in the second language classroom because teachers' responses to students' writing can vary according to how they perceive their roles as L2 writing teachers. De Guerrero and Villamil (2000) identified nine categories of conceptualized roles of ESL teachers such as considering the teacher as "cooperative leader," "knowledge provider," and "challenger." The teacher who perceives himself or herself as cooperative leader guides and helps students learn by constantly encouraging them. The teacher who falls in the knowledge provider group considers his or her role to be that of the source of language input to which students are exposed. In the third group, teachers are trying to make students learn English despite its many difficulties. Their role is to enlighten the potential abilities of students, to construct knowledge with students, to correct students' mistakes, and to help students develop their language proficiencies. The role that teachers keep in mind for themselves in the second language classroom should influence teachers' feedback, influencing how the feedback may vary in form, in the techniques, and in focus on different errors.

\subsubsection{The Role of Feedback in Process-Based Writing Instruction}

Depending on the approach teachers take in their writing instruction, the role of feedback has been defined in different ways. In a product-oriented approach to writing instruction, feedback has usually been provided to students' final pieces of writing as a form of evaluation or error-correction. However, in a process-oriented approach, the role of teachers' feedback to students' writing seems to be defined as a continuous response to students' writing throughout the writing process. That is, teachers' response to students' writing means much more than written feedback produced on their students' final products (Freedman 1987). Teacher response includes teacher-student individual conference and arranging the class activities to include peer response. According to Freedman (1987), feedback includes "all reaction to writing, formal or informal, written or oral, from teacher or peer, to a draft or final version."

\subsection{Types of feedback}

Patterns of feedback have been presented in slightly different ways by different researchers. Beason (1993) listed the categories of written feedback as follows: 1) identifying 
a problem (e.g., "coherence" "transition" "spelling"); 2) providing possible options or direction, not editing (e.g., "Can you explain more clearly?" "It would be more persuasive if you add the opposition"); 3) providing actual deletion, punctuation, or language needed (e.g., "Drop this"); 4) praising (e.g., "Great!" "Very nice"); 5) praising and suggesting (e.g., "Nicely said but elaborate some more"); 6) topical commenting (e.g., "This is a very popular topic!"). Ferris et al. (1997) presented general feedback types of written teacher responses:

1) Asking for further information.

2) Giving directions, suggestions, or requests for revision

3) Giving the student new information that will help him or her revise.

4) Giving positive feedback about what the student has done well.

The feedback can be given in the form of questions, statements, and imperatives and exclamations. Using various hedges such as "please," "maybe," "could," and "might" in the comments can soften the tone of teachers' responses. Ferris (1997) also suggested that the feedback should vary depending on the nature of the student writing and the strengths and weaknesses of the individual student.

According to Kassen (1990), feedback can differ in the way the teacher informs the learners of their mistakes in their writing. Feedback can include criticizing, suggesting error location and types, providing the correct form, asking the student to rewrite the correct form, and evaluating. In the second language classroom, feedback has typically focused on the correctness of form in students' writing. Therefore, no feedback from the teacher can be interpreted as implying that what the student wrote was correct (Chaudron, 1988).

\subsection{Types of Errors Addressed in Feedback}

While trying to suggest a better method to respond to students' writing, Ashwell (2000) presented the major types of errors commented on, categorizing them either as form feedback or content feedback. In the study, indirect feedback such as underlining or circling was favored in correcting errors of lexical choice, articles, spelling, prepositions, punctuation, agreement, and verb tense. The content feedback dealt more with organization, paragraphing, and relevance. The main types of problems in content feedback were comprehensibility, clarification, expressions, repetition, cohesion, ideas, and effective conclusion.

Ferris and Roberts (2001) also described the error categories in teacher feedback while examining the effect of different degree of explicitness of feedback. They chose five most frequent error types in a sample of 5707 errors by 92 ESL writers (Chaney, 1999). 
Their categories were verb errors, noun- ending errors, article errors, wrong word, and sentence structure.

\section{Method}

The primary goal of the study is to describe how the self-efficacy of EFL writing teachers was related to the feedback they provided on their students' writing. The following part will describe the rationale for design of the study and methodology used to examine the selfefficacy of EFL writing instructors and their feedback on student writing. This will conclude with a description of the context where data were gathered.

\subsection{Settings}

This study is conducted in the first semester of the academic year 2016-2017. The researcher was a participant as I was working as a part-time teacher in the College of Education for Humanities, Al-Muthanna University.

The class size varies from 100-160 students depending on each section from first stage students to fourth year students. Students are assigned from four to six writing assignments related to their readings in the class throughout the semester.

\subsection{Teacher Participants}

Participants that are included ten full-time EFL writing instructors in two (College of Education for Humanities, Al-Muthanna University and College of education for Humanities in Thi-Qar University. The participating teachers for the study had varying levels of teaching experience.

The participants are differed not only in their educational experiences and ages but also in their levels of self-efficacy. They also varied in their teaching experience and they used different types of feedback on their students' writing. Other background information of the participants is presented in the following tables from 1 to 4 .

Table .1 Participants' Educational Levels

\begin{tabular}{|l|l|l|l|l|}
\hline & Demonstrators & Master's Degree & $\begin{array}{l}\text { Doctoral } \\
\text { degree }\end{array}$ & Total \\
\hline Number & 2 & 8 & 5 & 15 \\
\hline Percent(\%) & 13.3 & 53.3 & 33.3 & 100 \\
\hline
\end{tabular}




\begin{tabular}{|l|c|c|c|c|c|c|}
\hline & $\begin{array}{c}25- \\
30\end{array}$ & $31-35$ & $36-40$ & $41-45$ & $46-50$ & Total \\
\hline Number & 3 & 3 & 7 & 1 & 1 & 15 \\
\hline Percentage (\%) & 20.0 & 20.0 & 46.7 & 6.7 & 6.7 & 100 \\
\hline
\end{tabular}

Table.3 Participants' EFL Teaching Experiences

\begin{tabular}{|l|c|c|c|c|c|}
\hline & $0-5$ years & $5-10$ years & $\begin{array}{c}10-15 \\
\text { years }\end{array}$ & $\begin{array}{c}15-20 \\
\text { years }\end{array}$ & Total \\
\hline Number & 2 & 7 & 2 & 4 & 15 \\
\hline Percentage (\%) & $13.3 \%$ & $46.7 \%$ & $13.3 \%$ & $26.7 \%$ & $100 \%$ \\
\hline
\end{tabular}

Table 4 Types of classes taught by participants

\begin{tabular}{|l|c|c|c|c|}
\hline & $\begin{array}{c}\text { Freshman } \\
\text { English }\end{array}$ & TWE writing & $\begin{array}{c}\text { Intermediate } \\
\text { EFL writing }\end{array}$ & Total \\
\hline Number & 8 & 1 & 6 & 15 \\
\hline Percentage (\%) & $53.3 \%$ & $6.7 \%$ & $40.0 \%$ & $100 \%$ \\
\hline
\end{tabular}

\subsection{Data Collection Procedures}

Several instruments for collecting data are incorporated in the study: a formal semistructured interview with each instructor and with several students in the instructor's class, a questionnaire on the instructor's writing and teaching experience and self-efficacy, sample documents of student writing voluntarily submitted to the researcher, and anecdotal observation notes.

My role as a researcher was restricted to that of an observer as participant (Merriam, 1998) because the study dealt with a subjective topic. Most of the data were analyzed qualitatively using a constant comparative approach. In addition, some of the data from the questionnaires produced descriptive statistics.

\subsection{Interviews}

A formal semi-structured interview was conducted in Arabic during the first semester of the academic year 2012-2013. Several interviews were conducted during this period. Most interviews lasted from forty minutes to an hour. 
During the interviews, information was requested that focused mainly on the teachers' previous experience teaching writing and on their degree of confidence in academic writing in general as well as that in English. Participants were asked to evaluate their perceived strengths and weaknesses as EFL writing teachers. Equally important was to inquire into their teaching goals in their EFL writing class, and their method of giving feedback to their students. The interviews main point in addition to my own notes were translated into English

During the interviews, information was requested that focused mainly on the teachers' previous experience in foreign language (English) writing, on their experience of teaching English writing, and on their degree of confidence in academic writing in general as well as that in English. Participants were asked to evaluate their perceived strengths and weaknesses as EFL writing teachers. Equally important was to inquire into their teaching goals in their EFL writing class, and their method of giving feedback to their students. I attempted to cover the following basic questions in each interview:

1-When you write in English, how you proceed? What is the main source of difficulty?

2-What do you think good writing is?

3-Do you consider yourself a good or competent writer in English?

4-In what types of writing do you feel more confident or less confident?

5-How is it different teaching those writing styles?

6-How do you define "a good EFL writing teacher”?

7- What is your goal as a university EFL instructor?

8-What do you comment on in your students' writing? Why or why not?

9-Are there any guidelines from your supervisor/department on suggested kinds of feedback?

\subsection{Questionnaires}

An in-depth questionnaire on the participants' writing experiences and their self-assessed self-efficacy was administered to provide supporting data in the study. These questionnaires were helpful for data collection and analysis because teachers' efficacy beliefs should be recognized as a very sensitive issue not easily revealed in interview.

Questionnaires were provided in English to all twenty participants before the interviews. Requested information included the instructor's age, years of teaching experience, years of education, beliefs concerning and experience in EFL writing skills and tasks, writing selfefficacy, and so on. In the questionnaire, participants were asked to measure their English 
proficiency and writing ability, as well as their abilities to encourage and achieve students' development in writing English.

The Writing Self-efficacy Scales developed by Shell, Murphy, and Bruning (1989) were adapted and modified for the questionnaire because parts of the original questions were not suitable for the research context. The self-efficacy instrument consisted of two scales. The first scale had ten items to measure participants' confidence in their ability to perform certain writing tasks. The second scale contained six items to rate the participants' confidence in performing particular writing skills, such as grammar, word use, composition structure, and mechanical skills. Participants might provide a rating from 0 to 10 as a measure of their self-efficacy for each skill or task. Shell, Murphy, and Bruning (1989) reported reliability scores of .95 for the skills scale and .92 for the tasks scale. Factor analysis shows positive correlation between items and subscales, and a good number of researchers have considered them viable and continue to use the instruments.

\subsection{Writing Samples}

The sample writing documents for the study were provided by the teacher participants after they had removed the names of the students. Compositions were written by students of university EFL courses as classroom assignments were collected from the teacher participants. These samples had been evaluated and corrected by the participating EFL writing teachers throughout the semester. Multiple student writing samples were gathered from each participant.

In a study such as this, the purpose of which is to investigate teacher feedback on writing, examining actual teachers' feedback is the best and most authentic way to understand teacher performance (Kassen, 1990). Data that helped present a complete picture of EFL composition feedback included input from the teachers themselves about their own writing experience and philosophy of teaching writing, and actual samples of their feedback procedures with supporting data from the interviews and questionnaires. These feedback samples were also appropriate for obtaining qualitative and quantitative information about feedback behavior (Merriam, 1998). By looking at the corrected student writing samples in this study, the researcher was able to understand better the patterns of teacher feedback on students' writing and the interaction between the teachers' self-efficacy beliefs and their actual feedback.

Writing samples written by students varied widely in length and style according to what type of class each teacher participant taught during semester. 


\subsection{Data Analysis}

The constant comparative method, the researcher employed as a form of analyzing the data, was developed by Strauss (1987) for coding and analyzing data to yield a grounded theory. This method of analyzing data seemed useful for this study because I hoped to find "what is going on" in the field, to discover the complexity and variability of human action, and to understand the meaning that individuals made of their actions (Strauss \& Corbin, 1998). This method is also useful in avoiding forcing a preconceived theoretical framework onto the data by letting categories be derived from the data.

Quantitative, statistical analysis of the questionnaire responses and of certain aspects of the feedback provided by the teachers on students' writings was implemented in the study as well. In order to obtain a comprehensive picture of self-efficacy beliefs of the participants, combining both methods was necessary. In other words, statistical data for this study were not used to test hypotheses, but to describe a general representation of the efficacy beliefs of the participating EFL writing instructors, something that might be difficult to obtain with qualitative analysis of data. However, only descriptive statistics were used for the data because of the limited number of participants.

\subsection{Writing Experience}

There was a slight difference in the participants' writing experience in terms of the types of writing tasks and in terms of the language. In writing English, they reported that they paid more attention to some aspects of the language than to others. Although their overall ratings of amount of attention varied slightly from 6 to 8 on a 9-point scale, organization was the number one area they considered as important in writing. It was rated the highest, 8 and 9 , by $87.6 \%$ of the participants. Content was reported as the second important area $(80 \%)$ that they attended to when they wrote. Vocabulary was the next category that they focused on in writing. It might be surprising that they did not pay as much attention to grammar as other categories. However, it seemed that these participants considered themselves as advanced English writers who already possessed grammatical competence.

\subsection{Self-Perception of their EFL Proficiency}

With respect to several aspects of writing in English, grammar was considered the easiest, while creative ideas and transitions were rated as the most difficult aspect. To the question of self-evaluation of language skills in both languages, the participants perceived writing as their weakest among the four language skills. In English, only $26.7 \%$ of the 
participants rated their writing skills as excellent, while $53.3 \%$ perceived their reading and listening skills excellent. Speaking skills were rated excellent by $40 \%$ of the participants. Participants also found it important to have experience in the following writing types :

- Summaries of reading

- Personal stories

- Short term papers

- Journal articles

- E-mail

- Class Papers/reports

- Résumé

- Poems and creative stories

\subsection{Descriptive Analysis of the Writing Self-Efficacy Scales}

The original writing self- efficacy scales by Shell, Murphy, and Bruning (1989) was modified slightly to reflect the cultural context of these college-level instructors . Because the number of respondents for the scales was very limited, only frequencies of the responses were analyzed and compared among the participants.

Descriptive analyses of the writing efficacy scales partly addressed the second part of the first research question: Specifically, was there any difference in their self-efficacy in writing among participants according to their educational background? In fact, the participants with doctoral degrees reported a slightly higher writing self-efficacy in English than those with master's degrees. The mean response for self-efficacy in writing tasks and writing skills among the participants with doctoral degrees was 8.8, while the participants with master's degrees scored 6.8.

Tables 5 through 8 present the frequency of responses in percentages, and means and standard deviations, in each area of writing tasks and skills in English. In the area of writing tasks in English, participants perceived themselves fairly confident in most writing tasks. The average rating for different writing tasks was 8.4. It was not surprising that writing a letter to a friend was rated as the easiest task (mean rating was 9.4). Writing a resume and a lesson plan were the next easiest tasks (9.1 for both items). The participants felt the least confident in creating a short piece of fiction (6.1). Consistent with the result of the questionnaire above, the participants rated coming up with creative ideas as difficult compared to other aspects of writing. Writing a scholarly article for a professional 
journal in their field was also perceived as one of the areas in which they had the least confidence (7.6).

Table 5 Frequencies, Means and Standard Deviations for Writing Self-efficacy Items of Writing Tasks in English

\begin{tabular}{|c|c|c|c|c|c|c|c|c|c|c|c|c|c|}
\hline Item & 0 & 1 & 2 & 3 & 4 & 5 & 6 & 7 & 8 & 9 & 10 & $\mathbf{M}$ & SD \\
\hline $\begin{array}{l}\text { 1. Write a letter to a } \\
\text { friend. }\end{array}$ & 0 & 0 & 0 & 0 & 0 & 0 & 0 & 0 & 6.7 & 46.7 & 46.7 & 9.4 & .63 \\
\hline $\begin{array}{l}\text { 2. Prepare a resume } \\
\text { describing employment } \\
\text { history and skills }\end{array}$ & 0 & 0 & 0 & 0 & 0 & 6.7 & 0 & 6.7 & 6.7 & 20.0 & 60.0 & 9.1 & 1.5 \\
\hline $\begin{array}{l}\text { 3. Compose a one or two } \\
\text { page essay in answering } \\
\text { to a test question }\end{array}$ & 0 & 0 & 0 & 0 & 0 & 0 & 0 & 6.7 & 33.3 & 33.3 & 26.7 & 8.8 & .94 \\
\hline $\begin{array}{l}\text { 4. Write a term paper of } \\
15 \text { to } 20 \text { pages }\end{array}$ & 0 & 0 & 0 & 0 & 0 & 0 & 0 & 13.3 & 33.3 & 33.3 & 20.0 & 8.6 & .99 \\
\hline $\begin{array}{l}\text { 5. Author a scholarly } \\
\text { article for publication }\end{array}$ & 6.7 & 0 & 0 & 0 & 0 & 13.3 & 0 & 13.3 & 20.0 & 26.7 & 20.0 & 7.6 & 2.64 \\
\hline $\begin{array}{l}\text { 6. Author a short fiction } \\
\text { story }\end{array}$ & 13.3 & 0 & 0 & 6.7 & 6.7 & 13.3 & 0 & 20.0 & 13.3 & 20.0 & 6.7 & 6.1 & 3.2 \\
\hline $\begin{array}{l}\text { 7. Compose an essay } \\
\text { expressing your view on } \\
\text { a controversial topic }\end{array}$ & 0 & 0 & 0 & 0 & 0 & 6.7 & 0 & 13.3 & 40.0 & 13.3 & 26.7 & 8.3 & 1.4 \\
\hline $\begin{array}{l}\text { 8. Prepare lesson plans } \\
\text { for a class studying a } \\
\text { process of writing }\end{array}$ & 0 & 0 & 0 & 0 & 0 & 6.7 & 0 & 6.7 & 6.7 & 26.7 & 53.3 & 9.1 & 1.4 \\
\hline $\begin{array}{l}\text { 9. Write a brief } \\
\text { autobiography }\end{array}$ & 0 & 0 & 0 & 0 & 0 & 6.7 & 0 & 13.3 & 20.0 & 20.0 & 40.0 & 8.7 & 1.5 \\
\hline $\begin{array}{l}\text { 10. Compose a two page } \\
\text { essay on your philosophy } \\
\text { of education }\end{array}$ & 0 & 0 & 0 & 0 & 0 & 6.7 & 0 & 13.3 & 33.3 & 26.7 & 20.0 & 8.3 & 1.3 \\
\hline
\end{tabular}

However, responses varied a great deal because some of the participants with doctoral degrees had had experience in publishing an article, and these participants reported that they were confident in writing a journal article. It seems that the confidence in writing a journal article depended more on experience than did that of the other writing tasks. In a 
similar vein, writing a 15-20 page long term paper, a brief essay, or a biography was considered quite undemanding for most participants (8.6, 8.8, and 8.7 respectively). These results imply that experience in specific writing tasks increased one's confidence.

EFL instructors in this study generally felt very confident in almost all writing skills. The mean rating of their self-efficacy in different writing skills was 9.0. Responses to each item did not show a great discrepancy. Although some participants did not feel completely confident in certain writing tasks, they perceived themselves competent in basic writing skills. Writing exactly what they want to communicate was considered slightly more difficult.

It is interesting to recognize that the interview data presented slightly different findings on the participants' self-efficacy in writing skills. Regarding the use of certain parts of speech such as articles or prepositions, they said they would not be completely certain if their feedback would be correct. Although almost all participants did not report any difficulty in writing what they wanted to express, one participant commented that she felt less confident in writing when she could not express exactly what she wanted to communicate.

Table 6 Frequencies, Means and Standard Deviations for Writing Self-efficacy Items for Writing Skills in English.

\begin{tabular}{|l|l|l|l|l|l|l|l|l|l|l|l|l|l|}
\hline Item & $\mathbf{0}$ & $\mathbf{1}$ & $\mathbf{2}$ & $\mathbf{3}$ & $\mathbf{4}$ & $\mathbf{5}$ & $\mathbf{6}$ & $\mathbf{7}$ & $\mathbf{8}$ & $\mathbf{9}$ & $\mathbf{1 0}$ & $\mathbf{M}$ & SD \\
\hline $\begin{array}{l}\text { 1. Correctly spell all words } \\
\text { in a passage }\end{array}$ & 0 & 0 & 0 & 0 & 0 & 0 & 0 & 6.7 & 20.0 & 40.0 & 33.3 & 9.0 & .93 \\
\hline $\begin{array}{l}\text { 2. Correctly punctuate a } \\
\text { passage }\end{array}$ & 0 & 0 & 0 & 0 & 0 & 0 & 0 & 0 & 20.0 & 33.3 & 46.7 & 9.3 & .80 \\
\hline $\begin{array}{l}\text { 3. Correctly use parts of } \\
\text { speech }\end{array}$ & 0 & 0 & 0 & 0 & 0 & 0 & 0 & 6.7 & 40.0 & 20.0 & 33.3 & 8.8 & 1.0 \\
\hline $\begin{array}{l}\text { 4. Write a paragraph with } \\
\text { proper grammar structure }\end{array}$ & 0 & 0 & 0 & 0 & 0 & 0 & 6.7 & 0 & 20.0 & 33.3 & 40.0 & 9.0 & 1.1 \\
\hline $\begin{array}{l}\text { 5. Organize sentences into } \\
\text { paragraph to clearly } \\
\text { express a theme. }\end{array}$ & 0 & 0 & 0 & 0 & 0 & 0 & 0 & 6.7 & 20.0 & 33.3 & 40.0 & 9.1 & .96 \\
\hline $\begin{array}{l}\text { 6. Write a paper with a god } \\
\text { overall organization }\end{array}$ & 0 & 0 & 0 & 0 & 0 & 0 & 0 & 6.7 & 26.7 & 26.7 & 40.0 & 9.0 & 1.0 \\
\hline $\begin{array}{l}\text { 7. Write in a way that } \\
\text { captures what I want to } \\
\text { communicate }\end{array}$ & 0 & 0 & 0 & 0 & 0 & 0 & 0 & 0 & 40.0 & 26.7 & 20.0 & 8.7 & .83 \\
\hline
\end{tabular}


However, the specific types of writing skills in which they felt more or less confident showed similar result as those in English. They felt least confident in creating a fiction in English (6.1). Writing a letter to a friend was considered as the easiest writing task in English (9.4).

In line with interview data, these participants seemed to feel more comfortable with professional terminology in English. This may have resulted from the fact that they had been reading professional journal articles and books exclusively in English.

\section{The Relationship Between Writing Self-Efficacy and Educational Background}

Although the number of participants responding to the questionnaire was insufficient to generalize the findings, two notable results were found in the background questionnaire and in the writing self-efficacy scales. First, almost all participants perceived themselves as poor in creative writing. They reported they were better at analytical type of writing than at creative writing. Secondly, the participants felt more confident in English.

In the current study, it seemed that the participants' different experiences in writing influenced the discrepancy in their self-efficacy. Only one participant gave a 9 rating for creative writing.

Educational background may also have influenced how the participants perceived their efficacy in writing. As reported before, certain participants commented that they had not written as many papers during their master's program. Furthermore, after they became EFL instructors, they had not thought of whether their writing was good because they did not have any opportunity to write in English other than to give feedback on students' writing. However, some participants who had doctoral degrees or near-native fluency had written an article for a professional journal. Those who kept their writing opportunities reported they felt confident in a broader range of writing tasks and skills. They mostly rated themselves 9 or 10 on the scales.

When the participants had higher English proficiency, they felt more confident in writing skills in English. Quite a few participants in the study had received early education in English-speaking countries.

In summary, various aspects of educational background seemed to have influenced the participants' writing self-efficacy. The types of writing the participants had experienced during their master's or doctoral programs affected their confidence by reinforcing their familiarity in these writing tasks. 


\subsection{Descriptive Analyses of the Writing Samples}

Each participant gave me one set of student papers with their feedback on them. Ten samples were randomly chosen per class ( the total number was 75 papers). From these, I developed categories looking for consistencies and generalities to describe how the teachers provided feedback.

The participants in the study showed a variety of ways of giving feedback in different levels of EFL writing classes. Four major ways of giving feedback were observed: handwritten, verbal, emails, and no feedback. There were several participants who implemented peer feedback as a classroom activity among students with or without the feedback from the teacher.

First, most participants reported they mainly used handwritten comments directly on students' writing. However, they used different techniques in writing the feedback. Some participants directly rewrote the errors (mainly grammatical) or problematic sentences. They crossed out, circled, or underlined the errors and others identified the errors using codes for each type of errors and wrote them below or above the mistakes made.

Second, two participants sent their comments to their students through email as an alternative way. Students also submitted their assignments by sending them as attachment files. These teachers wrote a brief comment and/or suggestion about error patterns. For instance, one teacher chose a paragraph from the student's writing and put her comments with different colors. He believed this system had been more effective because students tended to read the comments when they were delivered electronically. However, only general or selective comments were given through email.

Finally, there were two instructors who reported they had chosen not to give any feedback on students' writing that semester. One reason was that one teacher was very busy during that semester. She gave final letter grades to the students without returning the students' writing. In her writing samples, several comments indicating the mistakes and general evaluation of the paper were observed. She reported that she had made those comments for her own information. The other teacher only checked if students had turned in the assignments because she had 150 students in a class and could not do more.

Regarding the location of feedback, most participants teaching freshman English classes gave corrective feedback exclusively in the margins. Generally, they gave letter or number grades at the beginning or at the end of the papers. 
Only one participant wrote a phrase such as "well-done," "good," "work on the grammar," or "need more support," that generally summarized the errors and evaluated the paper at the end.

\subsection{Feedback Categories}

Categories applied to the comments that were given: grammar, content, vocabulary, expression, organization, and mechanics. Those were determined after referring to previous research on feedback reported by Kassen (1990) and Ferris and Hedgcock (1998), interview responses of the participants, and their actual feedback samples.

The grammar category included errors in tense, mood, voice, verb agreement, verb morphology, articles, prepositions, modal verb usage, and syntax. In the area of vocabulary, incorrect word choice was the main feedback. Mechanical errors included capitalization, punctuation, and spelling. Errors related to the basic format of writing such as indentation, spacing, and the location of title were also grouped as mechanics. Response to content included the instructor's reaction to the writer's meaning, that is, agreeing or disagreeing, inquiring about the truthfulness or accuracy of the content, and suggesting elaboration of the writer's ideas. The category of expression consisted of appropriateness for written English, redundancy, and non-English usage. Organization referred to remarks about effective titles, topic sentences, paragraphing, introduction, development, transition signal, and conclusion. If it was an argumentative essay, successfulness of the argument was also regarded as feedback on organization.

Grammar was the most frequent concern in giving feedback on students' writing. Mechanical problems were also a great concern although there was variation in the individual papers. Non-English expression was ranked third among the participants teaching Intermediate writing courses. Vocabulary was also frequently corrected or suggested with greater variation than other categories among the participants. Contrary to what the participants reported, comments on content as well as organization were not produced very often in giving feedback on students' writing. Participants tended to summarize and gave suggestions on the student's problem or the strength in organizing his or her argument as an end-note comment at the end of the paper. Therefore, those general comments will be presented separately because frequency of comments does not describe the whole picture of multifaceted comments of the participants. Comments on organization as well as content 
differed greatly for each participant. Overall, the number of comments per words students produced did not differ greatly among the participants.

Table 7 Frequency of Comment Types in the Writing Course Samples

\begin{tabular}{|l|c|c|c|c|c|c|c|}
\hline & $\mathrm{G}$ & $\mathrm{V}$ & $\mathrm{M}$ & $\mathrm{E}$ & $\mathrm{C}$ & $\mathrm{O}$ & $\begin{array}{c}\text { Comments } \\
\text { Per Words }\end{array}$ \\
\hline P1 & 89 & 26 & 34 & 23 & 6 & 10 & .034 \\
\hline P2 & 59 & 4 & 44 & 46 & 13 & 26 & .024 \\
\hline P3 & 83 & 13 & 45 & 15 & 8 & 13 & .025 \\
\hline P4 & 19 & 4 & 3 & 15 & 2 & 0 & .0084 \\
\hline P5 & 178 & 26 & 28 & 34 & 3 & 4 & .082 \\
\hline P6 & 8 & 3 & 1 & 8 & 4 & 7 & $* * *$ \\
\hline P7 & 65 & 10 & 11 & 17 & 0 & 0 & .025 \\
\hline P8 & 83 & 8 & 27 & 6 & 0 & 2 & .038 \\
\hline P9 & 33 & 7 & 16 & 2 & 1 & 4 & .017 \\
\hline P10 & 30 & 2 & 20 & 6 & 1 & 11 & .034 \\
\hline P11 & 87 & 16 & 34 & 14 & 2 & 3 & .048 \\
\hline P12 & 0 & 0 & 0 & 0 & 0 & 0 & None \\
\hline
\end{tabular}

$\square \mathrm{G}=$ Grammar, $\mathrm{V}=$ Vocabulary, $\mathrm{M}=$ Mechanics, $\mathrm{E}=$ Expression, $\mathrm{C}=$ Content, $\mathrm{O}=$ Organization. Two participants did not submit their feedback samples. Thus, the analyses were made on 12 participants' feedback Therefore, the total number of feedback per a word the student produced was not calculated.

\subsection{Participants' views on writing feedback ( First Stage Students through Fourth Stage Courses ):}

One usually started with an encouraging remark and gave suggestions on the content and organization of the students' paper. She took the role of reader more so than evaluator in her comments.

"You really did a good job".

"The points are clear and ideas are very well organized".

Another instructor also preferred two or three paragraph long end comments. She did not make text-specific comments. She gave more suggestions on basic writing skills and habits such as revision although she used a similar pattern of giving suggestions to all students' papers. 
(1) I believe that if you keep up writing in English, your writing will improve much.

(2) If you can, it's absolutely necessary to revise your writing many times.

Her major area of concerns in giving feedback seemed to be grammar rules. She indicated that she believed learning the rules is important in students' writing. Thus, she provided rules of grammar in her comments with an example of actual mistakes. A third instructor produced end comments on her students' writing as well. Her students produced 582 to 1300 words in their first draft. She used a direct, sometimes negative tone in her comments and it was not easy to find compliments in her comments." Your paper lacks focus and coherence, and it contains far too many sentence-level errors". "This is an adequate treatment of the subject but your failure to establish clear logical connections between and among your ideas leads to a certain incoherence".

Another teacher usually circled an error and used a code, such as WF for wrong form, SV for subject-verb agreement, and CS for comma splice, in order to indicate the type of error the student had made. She asked students to fix their mistakes in their revised draft according to the code.

By contrast, an instructor used both Arabic and English in his feedback. He reported that she focused on sentence structures with a clear idea when she gave comments. He believed that she could help students express their ideas in English because he shared the native language. In addition, in writing courses ( second year courses ), students were able to write without serious grammatical problems. She crossed or circled out and wrote in the corrections below the text. Occasionally, she underlined certain verbs to indicate errors in subject-verb agreement. He tended to provide the explanation of her suggestions or corrections.

Generally, the other instructors teaching freshman English courses shared the tendency for commenting on surface-level errors. One instructor believed that freshmen needed the feedback on grammar and sentence structure rather than on content or organization. She did not give any feedback on content or on organization. That was one of the reasons she assigned her students to write personal essays. The number of words her students produced varied tremendously from 160 to 809 words, with many of them around 300 to 400 words. She crossed out, or underlined and inserted the correction above the text. She put question marks when she did not understand what the student had tried to say in the sentence. Without any end comments, she gave the students grades on the first page of the paper. She did not require revision of the text. 
Another instructor also gave students a grade without end-note comments. She taught more than 150 students in the semester. She mentioned that Arabic students' most serious problem in writing is "think in English." However, her feedback did not reflect her view. She provided comments mostly on sentence- level errors. She underlined and wrote comments below the text, circled out, slashed out, and used codes, such as $\mathrm{N}$ for noun form and $\mathrm{T}$ for tense, to indicate the category of the errors. She often inserted the correction with check marks.

A third instructor was highly suspicious of the effect of teacher feedback. She believed that feedback did not have any beneficial effect on students' writing and that instead it impeded its development. She remembered the feedback that she had received as a student as unpleasant and useless. Thus, her feedback consisted of circles indicating mistakes, one-word summary of the paper, and a grade. She did not return the papers to students.

A third instructor preferred clear and simple ideas expressed in students' writing. When she looked at students' writing, she searched for a main idea and how it was supported in the paragraph. At the beginning of the semester, she lectured on the basic structure of a paragraph and the concept of topic sentence, unity, and coherence.

A more realistic view was given by an experienced instructor who considered giving feedback as placing heavy demands on EFL instructors. However, she said she also had learned a great deal since her days as a student herself. She also believed writing could be developed faster than other skills if students received help from teachers or books. Nevertheless, it was difficult to find comments that were encouraging or gave an optimistic view in her feedback samples.

Through the peer feedback assignment, students could assess their own writing and obtain a sense of good writing. In their comments on the writing of a peer student, students summarized general weaknesses of the paper and gave suggestions or corrections in Arabic. One student wrote his comments in English. Many students gave feedback on organization such as supporting sentences for the topic sentence or the lack of a concluding idea. A few students pointed out the irrelevant content in the paper. Others commented on grammatical problems.

By contrast, when students were given feedback on their writing from the teacher, they first looked for a grade and any end-note comments. When they were required to revise their drafts, they looked at text-specific marginal comments. Several teacher participants indicated that they asked their students to write revised drafts. However, some of them only 
collected the revised texts, while others gave grades only on the final drafts. Prof. Chin commented and graded each draft. One student in her intermediate writing class seemed to correct

\subsection{The Relationship Between Self-Efficacy and Feedback}

In the present study, I would like to present an integrated analysis of the core categories of the data. I will arrange the primary categories in a set of relationships that represent the central phenomenon, the causal conditions, the intervening conditions, strategic actions, and their consequences.

I decided to identify the "teachers' conceptions of their role in teaching EFL writing." Throughout the interview, I was impressed by the fact that some aspects of teacher feedback seemed mostly influenced by whether the teacher had found a role in helping students' EFL writing. Teachers began writing instruction with different beliefs about EFL writing and different writing experience both in L1 and in L2. In their EFL classrooms, teachers seemed to encounter motivating or frustrating situations that influenced the patterns of providing written feedback. Accordingly, they developed their own efficacy beliefs in performing their role in teaching college-level EFL writing. Ultimately, they had to decide what they could or must do as EFL writing teachers within their college-level EFL classroom contexts. Therefore, whether a teacher perceived himself or herself as helping students improve his or her EFL writing with feedback was critical in strengthening the effectiveness of teacher feedback on students' writing. EFL writing teachers can produce effective feedback by clearly communicating their beliefs about L2 writing and criteria in their feedback in their EFL writing classrooms.

\subsection{Context}

In the current study, non-native EFL writing teachers seemed to have concepts of their own role in giving feedback on students' writing under different sets of conditions. In teaching EFL writing as non-native speakers of English, the teachers presented varying dimensions of characteristics of EFL writing in Iraq.

These categories for contextual conditions consisted of 1) a group of teachers with a clear conception of their role in teaching EFL writing, highly confident in performing the role as non-native EFL writing teachers, and highly positive of students' improvement in EFL writing (4 teachers), 2) a group of teachers with a clear perception of their role in teaching EFL writing, less confident in performing their role, and highly positive of students' improvement in EFL writing (1 teacher), 3) a group of teachers with a clear 
conception of their role as EFL writing teachers, highly confident in performing their role as EFL writing teachers, and less positive of students' improvement in EFL writing (3 teachers), 4) a group of teachers with a clear conception of their role as EFL writing teachers, less confident in performing their role as EFL writing teachers, less positive of students' improvement in EFL writing (2 teachers), 5) a group of teachers uncertain of their role in teaching EFL writing, confident in performing their role as EFL writing teachers, less positive of students' improvement in EFL writing (4 teachers), 6) a group of teachers uncertain of their role in teaching EFL writing, less confident in performing their role as non-native EFL writing teachers, less positive of students' improvement in EFL writing (2 teachers). Table 8 presents the categories of various conditions under which the 15 participants perceived their role in teaching EFL writing by giving feedback on students' writing.

In general, these EFL writing teachers who were non-native speakers themselves had felt greatly concerned and nervous about teaching undergraduate students how to write in English before they started teaching. Depending on their level of English proficiency and writing experience, the degree of uncertainty differed slightly among the participants. The participants who perceived themselves as lacking sufficient writing experience and proficiency indicated that they had felt less confident of their qualifications to teach EFL writing. It should be noted that they were generally confident in their English proficiency. Conversely, teachers with higher writing self-efficacy in English did not doubt their ability to teach how to write in English to Iraqi EFL learners.

Table 8 Summary of Groupings of Contextual Conditions in Teachers' Conceptions of their Role in Teaching EFL writing

\begin{tabular}{|l|c|c|c|c|}
\hline & \multicolumn{2}{|c|}{ Clear conceptions } & \multicolumn{2}{c|}{ Uncertain of their role } \\
\hline Confident & $\begin{array}{c}\text { Less } \\
\text { confident }\end{array}$ & Confident & $\begin{array}{c}\text { Less } \\
\text { confident }\end{array}$ \\
\hline High expectation & 4 & 1 & 4 & 2 \\
\hline Low expectation & 2 & 2 & 4 & \\
\hline
\end{tabular}

In teaching college-level EFL writing as non-native speakers of English, teacher feedback on students' writing was not influenced exclusively by their writing self-efficacy. In the Iraqi EFL writing context, teachers seemed to choose how they would give comments on students writing depending on whether they have clear concepts of their role as EFL writing teachers. The conceptions of their role as non-native EFL writing teachers can differ depending on the 
certainty of their role, the confidence of performing the role, and positive expectations of change in students' EFL writing. Teaching experience, the level of writing class, and the class size influences how these teacher participants chose their strategic action as a response to their teaching efficacy. Thus, they could build their own feedback effective in helping students improve their writing.

\section{Conclusions}

1. Non-native college-level EFL writing instructors' writing self-efficacy was high. However, their feedback did not reflect their efficacy beliefs about their writing.

The initial area of interest in the study was on the influence of EFL writing teachers' writing self-efficacy on their feedback practices. The teachers in the study were found to evaluate their writing ability as high. They perceived themselves as capable of handling almost all aspects of EFL writing skills such as grammar, syntax, and the organization of paragraphs. However, their self-efficacy in various writing tasks varied slightly depending on their writing experience. For instance, some teachers who had not published an article in professional journals rated themselves less efficacious in writing a journal article. These results are consistent with the research on self-efficacy (Bandura, 1997). According to Bandura (1997), self-efficacy differs depending on the range of types and levels of tasks that vary across different situations.

Strong writing self-efficacy in English among the participants in the study contrasted with the findings of previous studies that EFL writers had been known to go through frustrating incidents that could harm their self-efficacy in EFL writing.

The participants perceived themselves as poor at creative writing. This may be related to the finding that most of them did not think of writing as a pleasant experience.

The participants' strong efficacy beliefs in EFL writing seemed to result from their perceptions that they had received more training to write in English. The teachers in this study did not necessarily need successful writing experiences in a language to have strong writing self-efficacy. They seemed to perceive that they had learned how to write through their own writing experience. Thus, a source of their writing self-efficacy was their writing experience. Moreover, individuals must maintain the source of writing self-efficacy.

2. In many aspects of giving feedback, it is important that a writing teacher has a clear concept of the role he or she plays in helping students improve their EFL writing.

With respect to the effectiveness of feedback written on students' writing, Ferris and Roberts (2001) found that less explicit feedback was as helpful to students as feedback 
using specific codes when compared to a no-feedback condition. The direct correction has not been found to be more effective in helping students improve their writing over time (Lalande, 1982). Thus, a non-native EFL writing teacher does not need to feel restricted in giving feedback on students' writing when he or she guides students to improve their writing by using suggestions or codes.

In some EFL writing classrooms, teaching efficacy has a stronger influence on teachers' feedback on students' writing due to contextual factors. The teachers often had to deal with a large number of students or they could not devote much time to teaching writing in the course. They then tended to prefer less time-consuming strategies to produce feedback. In order to make an effort to develop effective feedback practice, the role of teaching efficacy becomes important. Teachers' conception of their role in teaching EFL writing acts as a mediating mechanism in their feedback practices. Thus, they do not feel disturbed or discouraged in seeking their goals in teaching EFL writing.

In performing their role successfully in teaching EFL writing, the findings suggested that teachers should accommodate their feedback to the level of their students' writing. Although the total amount of feedback given on students' writing remained similar across levels, substantial feedback on content and organization was given to students in intermediate writing classes while feedback in freshman English classes was exclusively on form. This seemed opposite to the suggestion by Zamel (1985) and Sommers (1982) that commenting on content and organization on the earlier stage of writing is useful for students. One possible explanation for this result is that students did not write multiple drafts of their writing assignments in freshman English courses. In addition, the types of writing assignments in different levels of classes also influenced the areas of concern in producing the feedback on students' writing. As claimed in Kassen's study, focusing only on the relative frequency of comments on types of errors would not provide a sufficient explanation of various aspects of teacher feedback. Thus, as discussed above, investigations on qualitative differences in feedback is needed.

In conclusion, although non-native EFL writing teachers' self-efficacy in writing has not been found directly to influence the teacher feedback produced on students' writing, the data in the study showed evidence that self-efficacy in teaching EFL writing can be crucial in explaining the different strategies these teachers chose in giving feedback. 


\section{EFERENCES}

Arva, V., \& Medgyes, P. (2000). Native and Non-Native Teachers in the Classroom, System, 28, 355-372.

Ashton, P. T., \& Webb, R. B. (1986), Making a Difference: Teachers' Sense of Efficacy and Student Achievement. New York: Longman.

Ashwell, T. (2000). Patterns of Teacher Response to Student Writing in a Multiple-

Draft Composition Classroom: Is Content Feedback Followed by Form Feedback the Best Method? Journal of Second Language Writing, 9, 227-257.

Bandura, A. (1986). Social foundations of thought and action: A social cognitive theory. Englewood Cliffs, N.J.: Prentice Hall.

Bandura, A. (1992). Exercise of Personal Agency Through the Self-Efficacy Mechanism, In R. Schwarzer (Ed.), Self-efficacy: Thought control of action(pp. 355394). Washington D.C.: Hemisphere.

Bandura, A. (1993). Perceived Self-Efficacy in Cognitive Development and Functioning, Educational Psychologist, 28, 117-148.

Bandura, A., Barbaranelli, C., Caprara, G. V., \& Pastorelli, C. (1996). Multifaceted Impact of Self-Efficacy Beliefs on Academic Functioning, Child Development, 67, 1206-1222.

Bandura, A., \& Jourden, F. J. (1991). Self-Regulatory Mechanisms Governing the Impact Social Comparison on Complex Decision Making, Journal of Personality and Social Psychology, 60, 941-951.

Bandura, A., \& Wood, R. E. (1989). Effect of Perceived Controllability and Performance Standards on Self-Regulation of Complex Decision-Making, Journal of Personality and Social Psychology, 56, 805-814.

Bandura, A. (1997). Self-efficacy: The Exercise of Control, New York: Freeman.

Bates, L., Lane, J., \& Lange, E. (1993). Writing Clearly: Responding to ESL Compositions, Boston: Heinle \& Heinle.

Beason, L. (1993). Feedback and Revision in Writing Across the curriculum classes, Research in the Teaching of English, 27, 395-422.

Bong, M. (1997). Generality of Academic Self-Efficacy Judgments: Evidence of Hierarchical Relations, Journal of Educational Psychology, 89, 696-709.

Brand, A. G. (1989). The Psychology of Writing: The Affective Experience, Westport, CT: Greenwood Press. 
Chaney, S. J. (1999). The Effect of Error Types on Error Correction and Revision, MA thesis, Department of English, California State University, Sacramento.

Clearly, L. M., \& Seidman, E. (1990). In-Depth Interviewing in the Preparation of Writing Teachers, College Composition and Communication, 41, 465-471.

Cohen, A. D. (1987). Student Processing of Feedback on their Compositions, In A.Wenden \& J. Rubin (Eds.), Learner Strategies in Language Learning (pp. 57-69). Englwood Cliffs, N.J.: Prentice Hall International.

De Guerrero, M. C., \& Villamil, O. S. (1994). Social-Cognitive Dimensions of Interaction in L2 Peer Revision, Modern Language Journal, 78, 484-496.

Dragga, S. (1988). The Effects of Praiseworthy Grading on Students and Teachers, Journal of Teaching Writing, 7, 41-50.

Emmer, E., \& Hickman, J. (1991). Teacher Efficacy in Classroom Management and Discipline, Educational and Psychological Measurement, 51, 755-766.

Fathman, A., \& Whalley, E. (1990). Teacher Response to Student Writing: Focus on Form Versus Content, In B. Kroll (Ed.), Second language writing: Research insights for the classroom (pp. 178-190). Cambridge: Cambridge University Press.

Ferris, D. R. (1995). Student Reactions to Teacher Response in Multiple-Draft Composition Classrooms, TESOL Quarterly, 29, 33-53.

Ferris, D. R. (1997). The Influence of Teacher Commentary on Student Revision, TESOL Quarterly, 31, 315-337.

Ferris, D. R., \& Hedgcock, J. (1998). Teaching ESL Composition: Purpose, Process, and Practice, Mahwah, N.J.: L. Erlbaum Associates.

Ferris, D. R., \& Roberts, B. (2001). Error Feedback in L2 Writing Classes: How Explicit does it Need to be?, Journal of Second Language Writing, 10, 161-184.

Freedman, S. W., Greenleaf, C., \& Sperling, M. (1987). Response to Student Writing, Urbana, IL: National Council of Teachers of English.

Gibson, S., \& Dembo, M. H. (1984). Teacher Efficacy: A Construct Validation, Journal of Educational Psychology, 76, 569-582.

Glaser, B. G., \& Strauss, A. L. (1967). The Discovery of Grounded Theory, Chicago, IL: Aldine.

Graves, D. H. (1994). A Fresh Look at Writing, Portsmouth, NH: Heinemann.

Green, P. S., \& Hecht, K. (1985). Native and Non-Native Evaluation of Learners' Errors in Written Discourse, System, 13, 77-97. 
Guskey, T. R., \& Passaro, P. D. (1994). Teacher Efficacy: A Study of Construct Dimensions, American Educational Research Journal, 31, 627-643.

Hayes, J. R., \& Flower, L. (1990). Identifying the Organization of Writing Processes, In L. W. Gregg and E. R. Steinberg (Eds.).

Hyland, K. (1990). Providing productive feedback. ELT Journal, 44, 279-285.

Hyland, F., \& Hyland, K. (2001). Sugaring the Pill: Praise and Criticism in Written Feedback, Journal of Second Language Writing, 10, 185-212.

Kassen, M. A. Responding to Foreign Language Student Writing: A Case Study of Twelve Teachers of Beginning, Intermediate, and Advanced Level French, Doctoral Dissertation, University of Texas at Austin, May, 1990. K154

Keh, C. L. (1990). Feedback in the Writing Process: A model and Methods for Implementation, ELT Journal, 44, 294-304.

Krashen, S. D. (1984). Writing, Research, Theory, and Applications, Oxford: Pergamon Institute of English.

Kroll, B. (1991). Teaching Writing in the ESL Context, In M. Celce-Murcia (Ed.), Teaching English as a Second or Foreign Language (pp. 245-263). New York: Newbury House/Harper Collins.

-Lalande, J. F. (1982). Reducing Composition Errors: An experiment, Modern Language Journal, 66, 140-149.

Lantolf, J. P. (2000). Sociocultural Theory and Second Language Learning, New York: Oxford University Press.

Liu, D. (1999). Training nonnative TESOL students. In G. Braine (Ed.), Non- native educators in English language teaching (pp. 159-176). Mahwah, N.J.: L. Erlbaum Associates.

Merriam, S. B. (1998). Qualitative Research and Case Study Applications in education, San Francisco, CA: Jossey-Bass Publishers.

McCarthy, P., Meier, S., \& Rinderer, R. (1985). Self-Efficacy and Writing: A different view of self-evaluation, College Composition and Communication,36, 465-471.

McKinney, M., Sexton, T., \& Meyerson, M. J. (1999). Validating the Efficacy- Based Change Model, Teaching and Teacher Education, 15, 471-485.

McLeod, S. (1987). Some Thoughts About Feeling: The Affective Domain and the Writing Process, College Composition and Communication, 38, 426-435. 
McLeod, S. (1995). Pygmalion or Golem? Teacher Effect and Efficacy, College Composition and Communication, 46, 369-386.

Medgyes, P. (1994). The Non-Native Teacher, London: Macmillan.

Midgley, C., Feldlaufer, H., \& Eccles, J. S. (1989). Change in Teacher Efficacy and Student Self- and Task-Related Beliefs in Mathematics During the Transition to Junior High School, Journal of Educational Psychology, 81, 247-258.

Pajares, F. (1994). Inviting Self-Efficacy: The Role of Invitations in the Development of Confidence and Competence Writing, Journal of Invitational Theory \& Practice, $3(1), 5-11$.

Pajares, F., \& Johnson, (1994). Confidence and Competence in Writing: The Role of Self-Efficacy Outcome Expectancy, and Apprehension, Research in the Teaching of English, 28, 313-331.

Pajares, F., \& Valiante, G. (1997). Influence of Self-Efficacy on Elementary Students' Writing, Journal of Educational Research, 90, 353-360.

Pajares, F. (1997). Self-Efficacy Beliefs in Academic Settings, Review of Educational Research, 66, 543-573.

Prawat, R. S. (1992). Teachers' Belief about Teaching and Learning: A Constructivist Perspective, American Journal of Education, 100, 354-395.

Raimes, A. (1983). Techniques in Teaching Writing, New York: Oxford University Press.

Reid, J. M. (1993). Teaching ESL writing, Englewood Cliffs, N. J.: Prentice Hall.

Reid, J. M. (1994). Responding to ESL students' texts: The myths of appropriation. TESOL Quarterly, 28, 273-292.

Reves, T., \& Medgyes, P. (1994). The Non-Native English Speaking EFL/ESL Teacher's Self-Image: An international survey, System, 22, 353-367.

Roebuck, R. F. (2001). Teaching Composition in the College Level Foreign Language Class: Insights and Activities From Socio Cultural Theory, Foreign Language Annals, 34, 206-214.

Santos, T. (1988). Professors' Reactions to the Academic Writing of Non-nativeSpeaking Students, TESOL Quarterly, 22, 69-90.

Schunk, D. H. (1991). Goal Setting and Self-Evaluation: A social Cognitive Perspective on Self-Regulation, In M. L. Maehr and P. R. Pintrich (Eds.), Advances in motivation and achievement (pp. 85-113). Greenwich, CT: JAI. 
Schunk, D. H., \& Schwartz, C. W. (1993). Writing Strategy Instruction with Gifted Students: Effects of Goals and Feedback on Self-Efficacy and Skills, Roeper Review, $15,225-230$.

Shell, D. F., Murphy, C. C., \& Bruning, R. H. (1989). Self-Efficacy and Outcome Expectancy Mechanisms in Reading and Writing Achievement, Journal of Educational Psychology, 81, 91-100.

Siegel, M. E. A. (1982). Responses to Student Writing From New Composition faculty, College Composition and Communication, 33, 302-308.

Sommers, N. (1982).Responding to Students Writing, College Composition and Communication, 33, 548-556.

Stough, L., \& Emmer, E. (1998). Teacher Emotions and Test Feedback, International Journal of Qualitative Studies in Education, 11, 341-362.

Strauss, A. (1987). Qualitative Analysis for Social Scientists, Cambridge :Cambridge University Press.

Strauss, A., \& Corbin, J. (1998). Basics of Qualitative Research. Thousand Oaks,CA: SAGE Publications, Inc.

Tschannen-Moran, M., Hoy, A. W., \& Hoy, W. K. (1998). Teacher Efficacy: Its Meaning and Measure, Review of Educational Research, 68, 202-248.

Vygotsky, L. S.(1978). Mind in Society, Ed. Michael Cole. Cambridge: Harvard University Press.

Wachholz, P. B., \& Etheridge (1996). Writing Self-Efficacy Beliefs of High- and Low Apprehensive Writers, Journal of Developmental Education, 19, 16-24.

Zamel, V. (1985), Responding to Student Writing, TESOL Quarterly, 19, 195-202.

Zamel, V. (1987). Recent Research on Writing Pedagogy, TESOL Quarterly, 21, 697715.

Zamel, V. (1995). Strangers in Academia: The Experiences of Faulty and ESL Students Cross the Curriculum, College Composition and Communication, 46, 506-521. Zimmerman, B. J., \& Bandura, A. (1994). Impact of Self-Regulatory Influences on Writing Course Attainment, American Educational Research Journal, 31, 845-862.

Ziv, N. D. (1984). The Effect of Tacher Comments on the Writing of Four College Freshmen, In R. Beach, \& L. Bridwell (Eds.), New directions in composition research (pp. 362-380). New York: The Guilford Press. 